\title{
Study of Cultivation Mode for Creative and Entrepreneurial Talents of Undergraduates in Applied Subjects
}

\author{
Wei Guo \\ Baicheng Normal University, Baicheng, Jilin, China \\ 4015936@qq.com
}

Keywords: Applied Subjects, Entrepreneurial Talent, Training Scheme, Security System

\begin{abstract}
The state department is pushing a further push towards entrepreneurship and innovation, the implementation opinions of the general office of the state council on deepening the reform of education innovation and entrepreneurship in institutions of higher learning, aiming to close the education with technology, economy and society and to accelerate the cultivation of creative entrepreneurial talent that is large, innovative and committed to the practice. This article focuses on the design and implementation of entrepreneurial talent training scheme for undergraduates in applied subjects.
\end{abstract}

\section{Introduction}

Application-oriented undergraduate colleges have certain advantages in cultivating innovative and entrepreneurial talents, and are the highland and demonstration place for education innovation and entrepreneurship in universities. From the perspective of application type, such colleges and universities can cultivate practical applied technical talents and provide technical and technical guarantee for innovation and entrepreneurship.

From the perspective of undergraduate course education, this kind of colleges and universities to cultivate professional theory knowledge, with the application of scientific research innovation ability and comprehensive quality compound talents, provide quality assurance for innovation entrepreneurship. As a local application-oriented undergraduate college, education should also be promoted for its own development. Local applied undergraduate colleges and universities can be combined with local economic development and industry characteristics, clarify the idea of running the school, the orientation of development goals, teaching and service, establishing scientific talent training scheme will venture education into the teaching plan and credit system, the innovation effect of entrepreneurship education as an important index to evaluate the quality of the talents cultivation, scientific professional reform, promote the construction of teaching staff, to eventually achieve national innovation driven development strategy, promoting economic mass transfer efficiency is an urgent need to upgrade, promote the comprehensive reform of higher education, to promote higher quality undertaking employment for college graduates.

\section{Define the education talent training model for innovation and entrepreneurship}

Local applied undergraduate colleges may, according to the state council and the ministry of education issued a series of innovative entrepreneurship education guidance document and opinions, to innovative entrepreneurship education into the university personnel training system. Enrich the curriculum, promote the close combination of teaching, scientific research and practice, break through the weak links of talent training, and enhance the policy guidance of students' innovation spirit, entrepreneurship consciousness and innovation and entrepreneurship ability .Local undergraduate colleges and universities can be applied undergraduate education main talents training 
target and framework system, introduced the "comprehensive quality training system", "professional skill training system", "innovation entrepreneurship education system" mufti-dimensional, the government, schools, enterprises, social diversity education personnel training mode ".And the application-oriented undergraduate college innovation and entrepreneurship personnel training integrated with innovation and entrepreneurship education should be education throughout the whole process of innovation and entrepreneurship, which is a "four-in-one" innovation and entrepreneurship with wide popularity.

\section{Build and improve the education system for innovation and entrepreneurship, and build the education platform for innovation and entrepreneurship with the "four-in-one"}

Local undergraduate colleges and universities to build education teaching, project training, competition and entrepreneurship practice four platforms, the implementation of "discipline penetration theory - the practice experience of the real simulation, competition of skills training, start-ups incubator" four-in- one of the innovative undertaking education.

\subsection{Theoretical teaching course with subject penetration}

\section{1) Innovation and entrepreneurship basic knowledge course}

The school may offer a compulsory course ( 2 credit hours) of innovation and entrepreneurship basic course for all students.

Course content can be according to the theme of unit mode covers the entrepreneurs and entrepreneurial team, entrepreneurial opportunities and entrepreneurial risk, business resource management, business plan writing, the opening of new business processes, business legal basis, college students entrepreneurship policy, etc.

Through the study of this course, let the students understand the basic knowledge of business and entrepreneurship process, through a semester of class teaching, exert a subtle influence on stimulating students' innovative entrepreneurial awareness, cultivate students' innovative entrepreneurial emotions and hobby.

\section{2) Innovation and entrepreneurship specialty courses}

Schools can according to different subjects, in the form of restricted elective courses set up based on a series of professional, such as the start-up financing ", "business management", "business finance", "entrepreneurial marketing" and "technological entrepreneurship" innovation entrepreneurship curriculum characteristic (credits set to 4-10 credits), the curriculum especially must pay attention to professional courses and innovative business alignment. The theme of curriculum setting can run through the whole process of entrepreneurial preparation, early stage, entrepreneurial growth, entrepreneurial management and development strategy. Such courses in the school is the purpose of screening is to that part of the students, strengthen this part of the students' business knowledge and skills, training for the society at the same time to have professional skills, innovative spirit and entrepreneurial ability of potential entrepreneurs.

\subsection{The training experience of real simulation}

The training of innovative and entrepreneurial talents cannot be separated from the practical training course of innovation and entrepreneurship, which mainly includes innovation and entrepreneurship activities and practical operations. School by early special curriculum innovation entrepreneurship courses and innovation business, accurate positioning students with strong entrepreneurial intention, set up the innovative entrepreneurial elite training class, to conduct a comprehensive accurate innovation entrepreneurship education. Teaching curriculum, on the basis of the foundation and 
characteristics of entrepreneurship curriculum, add deepen the entrepreneurship education curriculum, especially the introduction of such as the whole true practice experience course (credits set to 5 credits).Colleges and universities should integrate education resources, set up education training platform for innovation and entrepreneurship, and conduct all-real simulation training for students of elite classes through sand table, entrepreneurial software and teaching case database. Student declaration for innovative start-ups, after approval, teachers lead students to simulate the complete company business registration, tax registration and new enterprise run by the business process, then the company supplies procurement, production, product sales and other trading simulation operation, at the same time in administrative, personnel, sales, procurement, finance to complete the operation of the company each work of the company management. Simulation training aims to "take the student as the main body", in the practice under the guidance of teachers by students' full participation, independent operation, independent management management pattern, make the student as if place oneself in the market operation, improve the students' innovative entrepreneurial skills.

Practical training simulation teaching, the school also based on the multilevel needs of students, combined with a professional internship practice platform resources, lead the students out of the campus to workshop, construction site practice, such as, to enterprises participate in the management of operations, and will visit team, business canvas, hatch and capital docking, such as the introduction of practical training class set up a personalized, multilevel training training practice.

\subsection{Competitive skills training}

In order to test the learning effect of students' innovation and entrepreneurship and stimulate their innovation and entrepreneurship potential, competitive skills training can be carried out.

Field innovation entrepreneurship competition into schools, to select the best projects recommended to participate in provincial or national level, such as "Internet + double innovation competition,", "youth innovation competition", "Challenge cup entrepreneurship competition" college students entrepreneurship competition. Before innovation entrepreneurship competition entries, schools can review the selection, in view of the seed team to give professional guidance to mentors group, by mentors group for a project for comprehensive training programs, promoting innovation of entrepreneurial teams participating skills, improve the winning probability. A group of entrepreneurial mentors can be mentored on campus entrepreneurship and hire outside the campus has a rich experience of teachers, and with successful experience outside, college students entrepreneurship support policy agency officials, college students' entrepreneurship and the guidance of the support system and risk investors, etc, for entrepreneurial teams give technology, information, policies, skills, knowledge and capital support. Through innovation entrepreneurship competition Students can develop innovative entrepreneurial vision and ideas, can match in the process of participating the winning team and other good, clear the strengths and weaknesses of their own team, targeted to improve and improve the team, to enhance the practice of innovative entrepreneurial skills, entrepreneurial laid a solid foundation for the independent innovation. Students take part in the innovation entrepreneurship competition, the guidance of mentors group, students actively participate in, some entries can be perfected, favored by the investors in the process of competition, investment funds, accelerate innovative start-ups, start new businesses, to complete the project from the simulation, display to the transformation of the implementation, profitability, complete innovation in colleges and universities entrepreneurship education, the purpose of conveying bed entrepreneurial ability of qualified personnel for the society. 


\subsection{Incubation and growth platform for innovation and entrepreneurship projects}

Innovative start-ups to fall to the ground to start the development of new businesses and in good health, get more attention and investment capital input, just rely on students to participate in the innovation entrepreneurship competition is not enough, can stand out from the competition and create a new project of enterprise, after all, is one of the few of this time also need to innovate business incubator base construction and upgrade of the project, in order to promote the success rate of entrepreneurial innovation. At present, there are many incubation bases have the function of incubator incubator, different incubation base has its own characteristics, but, in view of the construction of the incubator innovation in colleges and universities entrepreneurship education, need according to the objective conditions and the future demand for development of students to construct and perfect. According to the students' innovative start-up project, can on campus, advocate building type custody business incubator incubator innovation, for college students' innovative undertaking hatching platform, mainly for college students' innovative entrepreneurial project provides free or paid the office space, regular training, entrepreneurship project graduation roadshow, investors docking services such as training, help college students project can quickly through infancy, grow up to have the opportunity to get more investment. For hatching patterns and improve the college campus, campus incubator can be upgraded to relying on colleges and universities under the passenger space, it is a creative prototyping work space, equipped with all kinds of tool materials, with an incubator to compare, it offers a wider range of services, embodies the marketization, specialization, integration and networking features, emphasize the innovation and entrepreneurship, the combination of online and offline, incubation and investment. Able to move into the hackerspace is the main group of elite can accept innovation entrepreneurship education under the applied professional students, students and geeks will happen in the ideas of the collision, experiment, creating, improving and learning and sharing, students' divergent thinking and the ability to "crossover" to receive the cultivation of the remarkable achievement. The hackerspace can provide all kinds of resources, including professional and technical resources, such as $3 \mathrm{~d}$ printers, carving machine, and various kinds of raw materials such as physical resources, and guest room can provide office space for entrepreneurs and introduce investors, it is for the students innovative undertaking enterprise to provide low-cost, one-stop services and help the growth of integrated services platform.

\section{Innovation and entrepreneurship talent training support system}

Where in order to achieve the innovation of the applied undergraduate colleges and universities entrepreneurship education system of all the education target of training innovative entrepreneurial talent for the society of double and cultivating qualified and talented, need configuration innovation entrepreneurship education support security system at the same time, to double the escort and the entire education.

\subsection{Education's faculty allocation, forge a high level of dual-creation mentor team}

Education requires good teacher resources for college students to innovate and start businesses, also need a group of teachers and a group of mentors with teaching and creative guidance skills.Local applied undergraduate colleges and universities can be according to the actual situation of the school teachers, reasonable cultivation and introduction of dual and teachers' teaching ability, meet the innovative entrepreneurial education training system with characteristics of theory teaching, teaching and practice teaching course requirements. Schools can increase Innovation and entrepreneurship teacher through budget funds, the division of effective organization domestic innovation 
entrepreneurship training for teachers, to go abroad to visit, exchange of experience, project development cooperation, such as training methods, and strengthen the double and feedback, the content of the training content and training to strengthen the training content teaching effect, build and perfect fit for the double and the curriculum system of our school. Meanwhile, the school should enhance mentors of support and introduce, set up and perfect the government such as university students' employment in the field of entrepreneurship policy advisor and labor and social security departments, the influential business elite, college students star entrepreneurs create guest, with double and influence in the field of visiting professor, entrepreneurial education teaching ability of teachers, double with professional practice ability and teachers, angels and other team members. To campus teaching mentor, performance as the scale, the entrepreneurship mentors in the case of the theory teaching and practice guidance to test and inspection, to pay for the power, the implementation of the mentors reward system, to implement a mentors to development plan, perfect mentors hiring, salary, benefits, social security, position and rank promotion and performance management and other supporting system, establishing identity and the safeguard mechanism, improve the mentors. Mentor group configuration for the outside experts to social resources, fully integrated school to school double gen talent training demand and the demand of outside experts as a starting point, choose a responsible experts to guide college students entrepreneurial ability, the experts from the department of industrial policy, familiar with the market rules and the rules of the department, technology innovation and mastering the rich management experience in the field of different departments, such as they in such aspects as capital, technology, market has a wealth of resources.

\subsection{Campus dual - innovation culture construction drive, strengthen the application of professional students dual - innovation behavior choice motivation}

For Innovation and entrepreneurship personnel training in colleges and universities, a basic starting point is to arouse the enthusiasm of students' double gen behavior choice and participation, and in order to strengthen the Innovation and entrepreneurship behavior motivation, double the campus cultural construction is indispensable. On the design of the double and the talent training scheme, the need to "cultivate innovation entrepreneurship education" + professional construction of the blend, and in order to arouse the enthusiasm of students' innovative entrepreneurial, with entrepreneurial intend to encourage students' active participation in the entrepreneurship education, can develop students' innovative undertaking credit authentication management method and the displacement, in view of the course, competition and awards, entrepreneurship practice effect results give corresponding credit authentication and other professional courses for credit, replacement priority support students' innovative undertaking and cultivating innovative undertaking new talent.

In the double-create education campus environment, it is necessary to stimulate and guide the innovation and entrepreneurship motivation of college students. Education is top-down at school level, but education is more than just a top-down approach. Can give students in colleges and universities to create a good double create campus cultural atmosphere, let the students have been bathed in a strong double create campus cultural atmosphere, Innovation and entrepreneurship activity by students, campus publicity of public information platform, we regularly organize with double gen education as the theme lectures, starts an undertaking the star's appearing, to fix double gen thinking not only in classroom, and grounding the cultural life of the student. Through Innovation and entrepreneurship campus environment construction, not only can stimulate students Innovation and entrepreneurship role of practice and willpower, also can promote students to actively 
participate in the bottom-up innovation entrepreneurship practice of the project, so as to achieve innovation in colleges and universities the teaching purpose of entrepreneurship education.

\subsection{Improving the education platform for the training and implementation of innovative talents} and highlight the achievements of education

In order to achieve the education goal of the dual-creation talent training program, colleges and universities must implement every education design link of the training program. To carry out the cultivation scheme cannot leave the funds investment, funding is smoothly to carry out the creative talents training, one of the important guarantee for colleges and universities should build the government, society and universities combination of diversified financing channels, and through the way of budget allocation double gen education special funds, make double gen talent cultivation education platform. Education platform can exists in the form of double and students' overall development center, the center is a double teaching field, and simulation training venues, competition venue, practical roadshow site, entrepreneurial culture environment site as a whole, provide students with entrepreneurial skills training, business plan simulation, business operation and start-up incubator service environment, entrepreneurial environment. Center provides services, such as teachers of allocation of resources to be able to reach every accept double gen education students, and the schools themselves to accept education must carry on the education of students of tracking management, guarantee the special funds use effect, training scheme of education goals are met.

\section{Conclusion}

All in all, under the background of the national business, carry out Innovation and entrepreneurship education in colleges and universities in our country, carries on the Innovation and entrepreneurship talent training is also the demand of social talent, is also our country to build an innovative country, implementation, "two one hundred goals" and the great rejuvenation of the Chinese nation the Chinese dream provide strong intellectual support needs. This article in colleges and universities choose suitable for double gen training applied undergraduate students as the research object, to build the students' innovative undertaking the talent training scheme, and puts forward some Suggestions of complete training goal. The content in this paper has been cultivated and implemented among the students of applied undergraduate major of our university, and has obtained preliminary results.

\section{Acknowledgement}

This research was financially supported by social science research project of the 12th five-year plan of Jilin education department, in the context of national entrepreneurship, Application-oriented undergraduate professional entrepreneurial talents training,No.201613.

This research was financially supported by the Jilin Social Science Foundation. Research on the countermeasures of promoting entrepreneurship education under the background of transformation and development of local undergraduate colleges universities.No.20165083.

\section{References}

[1] Opinions of the general office of the state council on deepening education reform of innovation and entrepreneurship in institutions of higher learning,General office of the state council,05.04,2015. [2] Zuming YOU,Research on education in university practice based on incentive theory from the perspective of comprehensive reform, Chinese adults education[J]2017(10). 
[3] Hongmei WANG,Analysis on education innovation and entrepreneurship based on investigation of entrepreneurial intention of Hebei university students, Journal of Shanxi university of finance and economics,[J]2015(11).

[4] Youmei Wang,Aimin YE,From Hackerspace to Wework,Function model and service path based on innovation 2.0,Study on electrochemical education[J]2015(11).

[5] Zhiya CHEN,Strengthen the thinking and exploration of the cultivation of innovative talents,Science and technology in Chinese universities[J]2015(09). 